\title{
Analisis Pola Asuh, Kontrol Diri, dan Moralitas Kepribadian Sebagai Faktor Kenakalan Remaja di Kota Bekasi
}

\section{Erik Saut H Hutahaean, Andreas Corsini Widya Nugraha, Tiara Anggita Perdini, Ryan Bastoro, Romaria Marbun}

\author{
Universitas Bhayangkara Jakarta Raya \\ email: erik.saut@dsn.ubharajaya.ac.id
}

\begin{abstract}
Abstrak
Artikel INFO

Diterima:01 Nov 2019

Direvisi :09 Maret 2020

Disetujui: 17 Mei 2020

DOl:

http://dx.doi.org/10.24014/

jp.v14i2.7812

Kenakalan remaja adalah perbuatan yang mengandung unsur kriminal dan dilakukan oleh individu pada usia remaja. Salah satu faktor penyebab kenakalan pada remaja berasal dari rumah tempat tinggalnya. Minimnya penanaman nilai moralitas di dalam kepribadian dan rendahnya kesadaran lingkungan dalam membentuk konsep kendali menjadi sorotan penting untuk memahami mengapa remaja berbuat nakal. Penelitian ini bertujuan ingin menganalisis faktor yang berpengaruh terhadap kenakalan remaja. Pengambilan data Penelitian dilakukan dengan menyebarkan skala kenakalan remaja, skala pola asuh, skala kontrol diri, dan skala moralitas kepada 300 remaja di Kota Bekasi. Remaja yang menjadi responden dipilih berdasarkan konsep usia di bawah 18 tahun, dengan pendidikan menengah pertama hingga menengah umum atau sederajat. Hasilnya memperlihatkan pola asuh yang buruk berperan menjadi faktor yang pengaruhi kenakalan remaja secara langsung. Hasil uji juga mendapatkan kontrol diri dan moralitas kepribadian dapat berperan menjadi mediator yang menghubungkan pola asuh buruk dengan kenakalan remaja. Kedepannya perlu dilakukan analisis secara lengkap tentang faktor yang dapat membentuk kontrol diri pada remaja, dan proses yang dapat menanamkan moralitas pada kepribadian remaja.
\end{abstract}

Kata kunci : analisis, kenakalan remaja, pola asuh buruk, kontrol diri, moralitas.

\section{Analysis of Parenting, Self-Control, and Personality Morality as Factors of Juvenile Delinquency in the City of Bekasi}

\begin{abstract}
Juvenile delinquency is an act that contains a criminal element and is committed by individuals at the age of adolescence. One factor causing delinquency in adolescents comes from the house where he lives. The lack of instilling, the value of morality in personality and the low awareness of the environment in shaping the concept of control become an important spotlight to understand why adolescents are naughty. This study aims to analyze the factors that influence juvenile delinquency. It carried retrieval of data The study out by spreading juvenile delinquency scale, parenting scale, self-control scale, and morality scale to 300 adolescents in Bekasi City. Respondents were recruited based on the concept of age under 18 years, with junior high school or senior high school, with junior high school education to general secondary or equivalent. The results show that poor parenting plays a role in directly affecting juvenile delinquency. The test results also get self-control and personality morality can play a role as a mediator connecting bad parenting with juvenile delinquency. It is necessary to do a complete analysis of the factors that can shape self-control in adolescents, and processes that can instill morality in adolescent personalities.
\end{abstract}

Keywords: analyzing, juvenile delinquency, bad parenting, self-control, morality

\section{Pendahuluan}

Kenakalan remaja banyak dijadikan sebagai landasan untuk membuat prediksi tentang perilaku di masa yang akan datang, ketika berada pada masa dewasa. Kejahatan yang dilakukan orang dewasa merupakan peningkatan karir dari catatan kenakalan ketika berada pada usia remaja (Piquero et al., 2012). Saat ini kajian tentang kenakalan 
remaja difokuskan kepada proses-proses yang dialami remaja, tentang hal-hal yang didapatkan remaja selama berkembang dan pada akhirnya tumbuh menjadi orang dewasa di masa yang akan datang. Pola pengasuhan orangtua merupakan wilayah yang dianggap sebagai pusat untuk melakukan kajian pencegahan dan penanganan. Keluarga dianggap menjadi lingkungan pertama, dan yang paling utama dalam mewujudkan proses-proses pertumbuhan dan perkembangan anak, melalui proses pola asuh ( $\mathrm{Li}, 2014)$. Ketiadaan pengasuhan yang efektif disamakan dengan hadirnya pola asuh yang buruk di dalam keluarga. Bentuknya berupa pengasuhan yang tidak tepat, dan pengasuhan yang banyak mengajarkan hal-hal buruk di dalam rumah, dan diterapkan kepada anggota keluarga. Pada akhirnya membentuk suatu kebiasaan dalam berperilaku, dan pengasuhan dijadikan sebagai rujukan oleh anak dalam menjalankan perilaku sehari-harinya.

Kebiasaan buruk menjadi bagian dari perilaku remaja, dan digunakan sebagai kerangka untuk berperilaku dalam berbagai situasi nyata, khususnya di dalam perilaku pergaulan sosial. Konsistensi perilaku buruk selanjutnya membentuk perilaku nakal, dan sudah bahkan banyak yang sudah masuk kepada tindak kriminalitas, hingga remaja berhadapan dengan proses hukum pidana. Data resmi yang dapat dilihat di dalam System Database Pemasyarakatan, memperlihatkan data remaja menjadi warga binaan pada Lapas Kelas II A Bekasi. 2013 sebanyak 14 tahanan anak (SDP, 2013), 2014 sebanyak 25 tahanan anak (SDP, 2014), dan 10 tahanan anak pada tahun 2015 (SDP, 2015). Trend data dari tahun-tahun sebelumnya memperlihatkan gerak yang paradoksikal dengan keadaan Kota Bekasi.. Fakta tersebut memperlihatkan kenyataan yang ironis, karena saat ini Bekasi sedang membangun Kota secara masif. Sangat disayangkan jika hasil pembangunan akan diisi oleh generasi yang memiliki historis terlibat kriminalitas, atau memiliki pemuda yang memiliki catatan kejahatan.

Hasil penelitian yang melibatkan anak-anak berusia 7 sampai 18 tahun mendapatkan fakta bahwa tekanan yang berasal dari keluarga berpengaruh secara positif terhadap moderate delinquency, secara lebih jelas dinyatakan bahwa subjek yang menghabiskan waktu sangat sedikit bersama keluarga cenderung memberikan perlawanan terhadap keluarganya (Rekker et al., 2015). Hasil studi yang dilakukan terhadap siswa Slovenian, menyimpulkan fakta bahwa kontrol diri dan moralitas merupakan faktor yang pengaruhi kenakalan remaja (Bertok \& Mesko, 2015). Kajian ilmiah lainnya mengungkap kenyataan bahwa kontrol diri yang rendah pada remaja terjadi karena buruknya upaya pengasuhan orangtua dalam mengajarkan cara mengendalikan diri (Delisi et al., 2003). Kajian yang dilakukan dengan teknik meta analisis mendapatkan fakta bahwa moralitas memiliki pengaruh terhadap kenakalan (Stams et al., 2006). Moralitas dapat gagal terbentuk sebagai akibat hilangnya pengasuhan positif dari orangtua yang pada akhirnya memengaruhi kenakalan (Bertok \& Mesko, 2015).

Moralitas juga berperan pada terbentuknya kenakalan remaja yang terjadi, seperti yang disebutkan pada penelitian bahwa ada indikasi kuat bahwa moralitas berperan pada perilaku agresif dan empati yang ditunjukkan oleh remaja (Wang et al., 2016). Moral menjadi sebuah rujukan untuk mengatur perilaku melalui aturan dan norma yang berlaku (Guglielmo \& Malle, 2019), yang mencakup standar benar atau salah dari suatu tindakan.. Moralitas kepribadian dapat dipahami melalui suatu bentuk perilaku yang memperlihatkan adanya perbuatan menundukkan kepentingan pribadi demi mewujudkan kepentingan moral yang ada di lingkungan (Frimer et al., 2011). Suatu karakter yang berdomain moral ialah semua perilaku yang merujuk pada hubungan interpersonal secara positif dengan orang lain (Narvaez \& Lapsley, 2014). Lingkungan rumah memiliki bagian dalam membentuk karakter kepribadian yang bermoral terhadap anggota keluarganya, secara khusus bagi anaknya (Bao et al., 2015). Peran pengasuhan orangtua dianggap gagal karena hubungan yang terbentuk di dalam keluarga tidak mampu mengajarkan konsep moral positif di dalam pribadi anaknya. Padahal konsep moral yang positif justru dapat menghambat pengaruh negatif dari 
lingkungan (Nas et al., 2005) . Perilaku nakal anak remaja bila dibiarkan akan membuat mereka terjebak di dalam perilaku nakal yang mengarah kepada perilaku yang tidak sesuai dengan norma moral, hingga kepada kriminalitas. Sebaliknya perilaku remaja justru menjadi tindak kriminal, karena tidak ada mekanisme kontrol diri yang kuat di dalam dirinya (Pratt et al., 2014).

Pengasuhan dari orangtua telah dinyatakan pada penelitian sebelumnya, sebagai faktor yang dapat memberikan pengaruh terhadap perilaku nakal anak. Peranan pengasuhan orang tua juga memberikan konsekuensi terhadap pembentukan moralitas dan kontrol diri pada anak-anaknya. Kemudian pada hasil penelitian yang pernah ada ternyata menunjukan bahwa moralitas positif ternyata dapat menghambat pengaruh buruk dari lingkungan untuk berbuat nakal. Kontrol diri yang lemah pada anak remaja dapat membuat dirinya ikut terlibat dalam suatu tindak kenakalan bahkan hingga menjadi pelaku kejahatan. Merujuk kepada hal ini hipotesis pada penelitian ini adalah: kenakalan remaja dapat dipengaruhi secara langsung oleh pengasuhan yang negatif dari orangtua, kontrol diri dan moralitas dapat menjadi variabel yang berperan membantu pengasuhan orangtua dapat berdampak secara tidak langsung terhadap kenakalan remaja (alur dapat dilihat pada bagan 1)

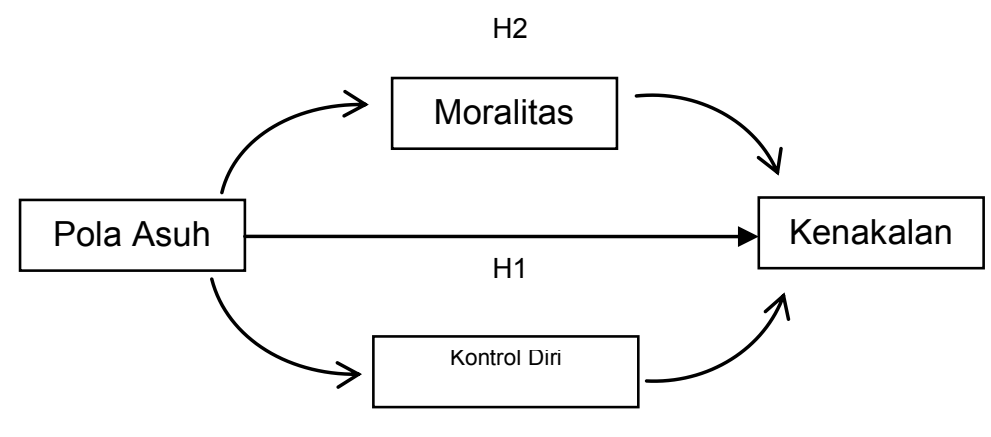

$\mathrm{H} 3$

Bagan. 1. Alur Hipotesis Penelitian

\section{Metode}

\section{Partisipan}

Penelitian ini melibatkan sebanyak 300 subjek berusia remaja, dalam rentang usia remaja awal dan remaja pertengahan, dengan batasan usia 12 sampai 17 tahun. Subjek dipilih berdasarkan domisili, yaitu bertempat tinggal di wilayah Bekasi Kota. Tim peneliti mengambil sampel penelitian ke empat titik di kota Bekasi, yaitu wilayah Bekasi Barat, Timur, Utara dan Selatan. Subjek diperoleh dengan mendatangi langsung ke lokasi dimana ada kerumunan siswa di luar lingkup sekolah, dan juga mendatangi satu sekolah menengah pertama. Jumlah subjek ditentukan berdasarkan mekanisme nonprobability sampling, teknik ini dipilih karena mempertimbangkan akses yang terbatas untuk dapat mengumpulkan subjek dalam cakupan yang sangat luas dan populasi yang sangat besar (Uprichard 2013).

\section{Pengukuran}

Data penelitian diperoleh dengan menggunakan alat pengumpul data berupa skala pengukuran variabel. Secara terperinci butir Skala Pengukuran Pola Asuh Buruk (SPPA) terdiri dari 8 butir pengukuran yang akan menggali data berbentuk data kontinum. Skala ini memuat perilaku yang mencerminkan perbuatan pengasuhan yang negatif orangtua di dalam keluarga dengan ciri-ciri keadaan ekonomi tergolong menengah kebawah, memperbolehkan mencuri demi kelangsungan hidup, keluarga yang suka bertengkar dalam rumah (Sudarsono, 2004). Contoh butirnya; "Di rumah orang tua saya 
berkata kotor kepada anak-anaknya".

Skala Pengukuran Kontrol Diri (SPKD) disusun dengan menggunakan 8 butir pengkuran, data kuantitatif didapatkan melalui konsep skala semantic differensial, yang merepresentasikan dua kutub; kesanggupan dan ketidak sanggupan mengendalikan diri (Owens \& Cecilia, 2007). Contoh butir untuk Kontrol Diri; dalam mengambil suatu tindakan. Subjek memberikan responnya dengan memberikan tanda pada salah satu kolom angka, angka 1 mengartikan subjek dalam mengambil tindakan tanpa perhitungan, angka 5 merepresentasikan bahwa subjek akan berfikir dengan akal sehatnya sebelum mengambil tindakan.

Skala Pengukuran Moralitas Kepribadian (SPMK) diususun dalam bentuk 8 butir pengkuran, dengan menggunakan bentuk pengkuran dua kutub yang berbeda, mencerminkan dua kutub moral yang bersebrangan; moral pribadi yang baik dan yang buruk. Skala moralitas disusun dengan menggunakan konsep mengenai moralitas kepribadian yang mencerminkan jujur, bisa dipercaya, penuh pertimbangan, dan berhati baik (Frimer et al., 2011). Contoh butirnya; semua karakter yang ada di bawah ini, saya merupakan orang yang: pilihan angka 1 mewakili bahwa subjek adalah pembohong, sedangkan angka 5 merepresentasikan bahwa subjek jujur. Respon subjek adalah dengan memberikan tanda pada salah satu angka yang disediakan.

Skala Pengukuran Kenakalan Remaja (SPKR), skala ini diukur melalui 8 butir pengkuran, dengan menggunakan prinsip penskalaan kontinum model semantik diferensial, yang memuat perilaku nakal remaja seperti kenakalan yang sudah terkait dengan perbuatan kriminal, penyimpangan norma, dan menginginkan kebebasan dari pengawasan orangtua (Dirdjosisworo, 1983). Contoh butinya; semua perbuatan yang ada di bawah ini saya pernah melakukannya. Angka 1 menggambarkan bahwa subjek dalam kehidupannya dikontrol dan dikendalikan oleh keluarganya, sedangkan angka menggambarkan bahwa subjek bebas dari pengawasan orang keluarga.
Analisis butir pengukuran dilakukan dengan menggunakan daya diskriminasi butir, salah satu analisis statistik yang dapat digunakan adalah dengan nilai koefisien korelasi antara skor butir dengan skor total butir (Azwar, 2009). Keseluruhan butir pada masing-masing variabel diuji kelayakannya secara tradisional dan sederhana, yaitu memilah butir-butir yang tidak berkorelasi dengan butir lainnya. Hasil dari uji daya diskriminasi mendapatkan sebanyak 3 butir instrumen pengkuran yang nilainya tidak layak. Terdapat 2 butir pengukuran dinyatakan gugur pada skala pengukuran pola asuh, dan didapatkan 1 butir yang gugur pada skala pengukuran moralitas. Sedangkan untuk pengukuran kontrol diri dan pengukuran kenakalan remaja semua butir yang diuji coba dinyatakan layak. Secara terperinci butir Skala Pengukuran Pola Asuh (SPPA) terdiri dari 6 butir $(0.390-0.528)$, Skala Pengukuran Kontrol Diri (SPKD) terdiri dari 8 butir $(0.378$ - 0.565), Skala Pengukuran Moralitas Kepribadian (SPMK) terdiri dari 7 butir $(0.353-0.604)$, dan Skala Pengukuran Kenakalan Remaja (SPKR) terdiri dari 8 butir $(0.273-0.519)$.

\section{Analsis data}

Data penelitian dianalisis dengan menggunakan teknik deskriptif kelompok kategori subjek, korelasi dan regresi linier dengan model mediator sederhana. Analisis deskriptif digunakan untuk menerangkan fakta tentang empat kelompok kategori dalam menjelaskan sluruh variabel dalam penelitian ini. Kontrol diri dan moralitas diuji terlebih dahulu, untuk diketahui apakah keduanya dapat dijadikan sebagai variabel yang dapat menghubungkan pola asuh yang buruk dengan kenakalan remaja. Analisis tidak hanya dilakukan secara satu-persatu, tetapi analisis regresi juga dilakukan untuk melihat efek pengaruh langsung dan pengaruh tidak langsung, yaitu dengan menggunakan teknik analisis signifikansi efek tidak langsung (Preacher \& Hayes, 2004). Analisis data dilakukan untuk melihat interaksi satu persatu antar variabel, dan interaksi tidak langung yang terjadi pada kenakalan remaja. 


\section{Hasil}

\section{Analisis Komparatif Deskriptif}

Analisis komparatif deskriptif dilakukan untuk mengetahui fakta-fakta deskriptif mengenai subjek penelitian. Adapun data deskriptif dianalisis berdasarkan jenis kelamin, status sekolah (negeri atau swasta), keadaan orangtua (lengkap atau tidak), status pekerjaan orangtua, dan urutan kelahiran. Data-data tersebut diuji untuk menemukan fakta-fakta empiris pendukung, untuk melengkapi temuan fakta yang sesuai dengan dugaan awal penelitian.

Tabel.2. Frekuensi dan Rerata Berdasarkan Jenis Kelamin, Sekolah dan Keadaan Orangtua

\begin{tabular}{clcccccc}
\hline & & \multicolumn{2}{c}{ Jenis Kelamin } & \multicolumn{2}{c}{ Sekolah } & \multicolumn{2}{c}{ Keadaan Orangtua } \\
\cline { 3 - 7 } & & L & P & Negeri & Swasta & Lengkap & $\begin{array}{c}\text { Tidak } \\
\text { Lengkap }\end{array}$ \\
\hline \multirow{2}{*}{ PA } & Frekuensi & 168 & 132 & 55 & 245 & 270 & 30 \\
& Rerata & 10,15 & 9,6 & $\mathbf{1 0 , 9 2 ^ { * }}$ & $\mathbf{9 , 6 8 ^ { * }}$ & 9,85 & 10,43 \\
KD & Frekuensi & 168 & 132 & 55 & 245 & 270 & 30 \\
& Rerata & 32,26 & 32,06 & 31,4 & 32,35 & $\mathbf{3 2 , 3 6 ^ { * }}$ & $\mathbf{3 0 , 5 ^ { * }}$ \\
M & Frekuensi & 168 & 132 & 55 & 245 & 270 & 30 \\
& Rerata & 28,18 & 28,37 & 27,78 & 28,37 & 28,41 & 26,96 \\
KR & Frekuensi & 168 & 132 & 55 & 245 & 270 & 30 \\
& Rerata & $\mathbf{1 5 , 1 7 ^ { * }}$ & $\mathbf{1 3 , 6 6 ^ { * }}$ & $\mathbf{1 5 , 6 ^ { * }}$ & $\mathbf{1 4 , 2 6 *}$ & 14,41 & 15,33 \\
\hline
\end{tabular}

Data yang ditampilkan pada Tabel.2 memperlihatkan bahwa penelitian ini melibatkan sebanyak 168 subjek dengan jenis kelamin laki-laki, dan 132 perempuan. Selanjutnya juga dapat dilihat ada sebanyak 55 subjek yang berasal dari sekolah negeri, dan 245 sekolah swasta. Hasil analisis deskriptif mendapatkan data tentang keadaan orangtua subjek, lengkap berarti masih memiliki ayah dan ibu (tidak bercerai). Tidak lengkap artinya tidak ada salah satunya atau keduanya, (orangtua bercerai dan karena meninggal). Data yang terkumpul mendapatkan 270 subjek dengan keadaan orangtua lengkap, dan 30 subjek dengan orangtua tidak lengkap.

Tabel. 3. Frekuensi dan Rerata Berdasarkan Pekerjaan Orangtua dan Urutan Kelahiran

\begin{tabular}{|c|c|c|c|c|c|c|}
\hline & & \multicolumn{2}{|c|}{ Pekerjaan Orangtua } & \multicolumn{3}{|c|}{ Urutan Kelahiran } \\
\hline & & $\begin{array}{l}\text { Keduanya } \\
\text { Bekerja }\end{array}$ & $\begin{array}{l}\text { Keduanya/ salah } \\
\text { satu tidak bekerja }\end{array}$ & Sulung & Tengah & Bungsu \\
\hline \multirow{2}{*}{ PA } & Frekuensi & 49 & 251 & 129 & 73 & 98 \\
\hline & Rerata & 10,32 & 9,82 & 10,03 & 10,06 & 9,63 \\
\hline \multirow{2}{*}{ KD } & Frekuensi & 49 & 251 & 129 & 73 & 98 \\
\hline & Rerata & 32,16 & 32,17 & 32,69 & 28,15 & 31,82 \\
\hline \multirow{2}{*}{ M } & Frekuensi & 49 & 251 & 129 & 73 & 98 \\
\hline & Rerata & 27,95 & 28,32 & 28,32 & 28,15 & 28,27 \\
\hline \multirow{2}{*}{ KR } & Frekuensi & 49 & 251 & 129 & 73 & 98 \\
\hline & Rerata & 15,16 & 14,38 & 14 & 15,05 & 14,77 \\
\hline
\end{tabular}

Data lainnya juga diungkap dalam penelitian ini adalah data pekerjaan orangtua, data ini dimaksudkan untuk melihat apakah orangtua subjek keduanya adalah pekerja, atau keduanya (juga salah satunya) tidak bekerja. Merujuk kepada data yang terkumpul; 49 subjek kedua orangtuanya bekerja, dan 261 subjek yang masuk pada kelompok kedua. Data mengenai poisi urutan kelahiran subjek juga diungkap 
didalam proses analisis; sulung, tengah dan bungsu. Data pada Tabel.2 memperlihatkan terdapat 129 subjek merupakan anak sulung, sebanyak 73 subjek merupakan anak tengah, dan 98 subjek merupakan anak bungsu. Jenis kelamin, sekolah, keadaan orangtua, pekerjaan orangtua, dan urutan kelahiran merupakan pengelompokan data yang akan digunakan untuk untuk melakukan uji komparatif nilai rerata skor subjek.

Hasil uji komparatif dilakukan untuk melihat perbedaan rerata skor keseluruhan subjek berdasarkan kelompok-kelompok yang sudah ditetapkan. Hasil hitung nilai rerata pola asuh berdasarkan sekolah, memperlihatkan skor yang berbeda secara signifikan dalam hal pola asuh diantara subjek yang sekolah di swasta dan sekolah di negeri. Pola asuh yang buruk diasumsikan lebih banyak pada terjadi pada subjek yang bersekolah di negeri. Kontrol diri lebih tinggi ditemukan pada subjek yang memiliki orangtua lengkap. Hasil uji komparasi nilai rerata berhasil mendapat nilai yang berbeda dalam hal kenakalan berdasarkan kelompok jenis kelamin. Subjek dengan jenis kelamin laki-laki mempunyai nilai rerata lebih tinggi dalam hal kenakalan, ketika dibandingkan dengan subjek jenis kelamin perempuan.
Data pada Tabel.2 juga memperlihatkan bahwa siswa sekolah negeri memiliki skor kenakalan yang lebih tinggi, dibandingkan dengan subjek yang bersekolah di swasta. Pada analisis tersebut di atas, berhasil memperlihatkan adanya perbedaan yang signifikan. (pada Tabel,2 tulisan dipertebal dan diberi tanda $\left.{ }^{*}\right)$. Hasil analisis berdasarkan kelompok identitas yang lainnya (pekerjaan orang tua dan urutan kelahiran), memperlihatkan adanya nilai rerata yang tidak berbeda secara signifikan.

\section{Analisis Korelasional}

Berdasarkan kelompok jenis kelamin, pada variabel pola asuh, kontrol diri dan moralitas memperlihatkan perbedaan skor rerata tidak signifikan. Hal tersebut merepresentasikan bahwa kelompok laki-laki ataupun perempuan secara umum memiliki rerata skor relatif sama. Berdasarkan kelompok sekolah (swasta atau negeri), variabel kontrol diri dan moralitas kepribadian juga tidak memperlihatkan nilai rerata yang berbeda. Berdasarkan orangtua bekerja, dan urutan kelahiran empat variabel yang diteliti skor reratanya tidak menunjukan perbedaan antara yang satu dengan lainnya.

\section{Tabel.4 Korelasi dan Pengaruh Langsung}

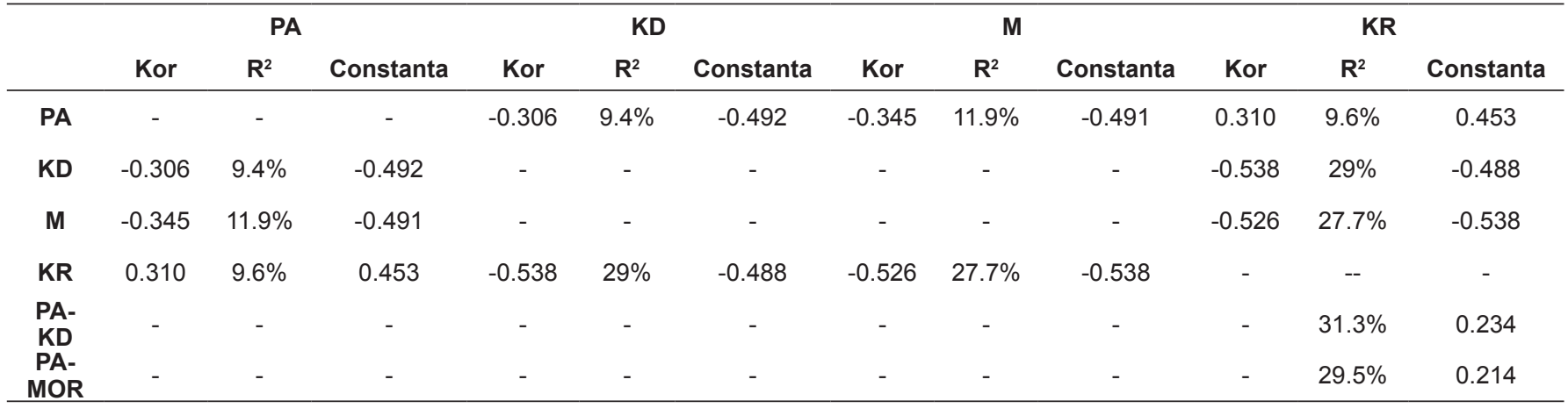

Uji korelasi antara pola asuh dengan kontrol diri mendapatkan hasil adanya hubungan diantara kedua variabel dengan nilai koefisien korelasi sebesar -0.306 . Pola asuh yang buruk memberikan pengaruh sebesar $9.4 \%$ terhadap kontrol diri remaja. Pengaruh yang dimaksud dalam hal ini juga dapat dilihat melalui nilai konstanta yang diperoleh ketika pola asuh yang buruk pengaruhi kontrol diri, setiap pola buruk meningkat satu kali akan diikuti dengan menurunnya kontrol diri sebesar -0.491 . Uji korelasi pola asuh juga dilakukan terhadap moralitas, hasilnya mendapatkan terjadinya hubungan dengan nilai korelasi -0.345 . Pola asuh yang buruk terbukti dapat memberikan pengaruh sebesar $11.9 \%$, dimana setiap pola asuh satu kali meningkat menjadi lebih buruk akan diikuti dengan menurunnya moralitas sebesar -0.491 . 
Uji korelasi antara kontrol diri dan kenakalan remaja memperlihatkan terjadinya hubungan pada kedua variabel, dengan nilai korelasi -0.538. Kontrol diri berhubungan secara berlawanan arah dengan kenakalan remaja, kontrol diri juga memberikan pengaruh sebesar $29 \%$ terhadap kenakalan remaja. Setiap kontrol diri meningkat sebanyak satu kali, akan diikuti dengan menurunnya kenakalan pada remaja sebesar -0.488. Uji korelasi terhadap moralitas dengan kenakalan remaja juga mendapatkan terjadinya hubungan dengan nilai korelasi sebesar -0.526 . Moralitas juga terlihat dapat memberikan pengaruh sebesar $27.7 \%$ terhadap kenakalan remaja. Setiap moralitas meningkat satu kali akan diiktui dengan menurunnya kenakalan remaja sebanyak -0.538 .

Hasil uji pengaruh bersamaan, dimana pola asuh buruk bersamaan kontrol diuji pengaruhnya terhadap kenakalan remaja, mendapatkan adanya peningkatan pengaruh terhadap kenakalan remaja. Pengaruhnya meningkat menjadi $31.3 \%$ jika dibandingkan ketika pola asuh memengaruhi kenakalan remaja secara langsung (9.6\%). Begitu juga ketika pola asuh bersamaan dengan moralitas diuji pengaruhnya terhadap kenakalan remaja, pengaruhnya meningkat menjadi $29 \%$. Pada saat pola asuh buruk diuji bersama kontrol diri, berhasil menurunkan nilai konstanta menjadi 0.234 . Ketika pola asuh diuji pengaruhnya terhadap kenakalan remaja nilai konstantanya lebih besar (konstanta 0.453). Sama halnya yang terjadi ketika pola asuh bersamaan dengan moralitas diuji pengaruhnya terhadap kenakalan remaja, pengaruhnya semakin bertambah menjadi
29.5\%. Pengaruh ini ternyata juga berdampak kepada menurunnya nilai konstanta menjadi 0.214 . Menurunnya pengaruh merujuk kepada nilai konstanta ketika kenakalan dipengaruhi secara langsung oleh pola asuh (konstanta 0.453).

\section{Analisis Kontrol Diri dan Moralitas Kepribadian Sebagai Mediator}

Sebelum variabel mediator diuji kelayakannya, penelitian ini berusaha terlebih dahulu melihat hubungannya dengan kenakalan remaja. Variabel mediator yang dimaksud adalah kontrol diri, dan moralitas kepribadian. Kontrol diri berhubungan dengan kenakalan remaja dengan pola yang berlawanan, nilai korelasi -0.538 . Hasil ini merepresentasikan bahwa kenaikan skor kontrol diri akan diikuti dengan menurunnya skor kenakalan remaja. Hasil hitung mendapatkan pengaruh kontrol diri terhadap kenakalan remaja adalah sebesar 29\%, setiap kontrol diri meningkat sebanyak 1 kali, akan diikuti dengan menurunnya kenakalan remaja sebesar -0.488 .

Begitu juga didapatkan hasil terjadinya hubungan dengan pola yang berlawanan, nilai korelasi -0.526 . Meningkatnya skor moralitas kepribadian akan diikuti dengan menurunnya skor kenakalan remaja. Hasil hitung sumbangan variabel moralitas memperlihatkan pengaruh sebesar $27.7 \%$, ketika skor moralitas kepribadian meningkat 1 kali akan diikuti dengan menurunnya skor kenakalan sebesar -0.538 . . Setelah uji korelasi dan regresi langsung, penelitian dilanjutkan dengan melakukan uji analisis efektivitas mediasi atau pengaruh tidak langsung.

Tabel. 5 Uji Kelayakan Kontrol Diri dan Moralitas Kepribadian Sebagai Mediator

\begin{tabular}{lcc}
\hline \multicolumn{1}{c}{ Langsung/Tidak Langsung } & S.e & Sig (two) \\
\hline Pola Asuh $\rightarrow$ Kenakalan Remaja & 0.803 & 0.000 \\
Pola Asuh $\rightarrow$ Kontrol Diri & 0.803 & 0.000 \\
Pola Asuh $\rightarrow$ Kontrol Diri $\rightarrow$ Kenakalan Remaja & 0.458 & 0.000 \\
Pola Asuh $\rightarrow$ Moralitas & 0.775 & 0.000 \\
Pola Asuh $\rightarrow$ Moralitas $\rightarrow$ Kenakalan Remaja & 0.046 & 0.000 \\
\hline
\end{tabular}

Hasil hitung uji kelayakan kepada kontrol diri dan moralitas kepribadian dilakukan melalui uji pengaruh secara langsung dan tidak langsung. Hasil uji pengaruh langsung memperlihatkan yang sejalan dengan uji korelasi (lihat juga Tabel.1). Uji interaksi 
langsung antara pola asuh dan kenakalan mendapatkan hasil kedua variabel dapat berinteraksi secara signifikan. Hasil hitung interaksi tidak langsung mendapatkan bahwa kontrol diri berhasil menghubungkan pengaruh pola asuh yang buruk terhadap kenakalan remaja. Maka dengan demikian interaksi antara pola asuh yang buruk terhadap kenakalan remaja dapat dimediasi oleh kontrol diri.

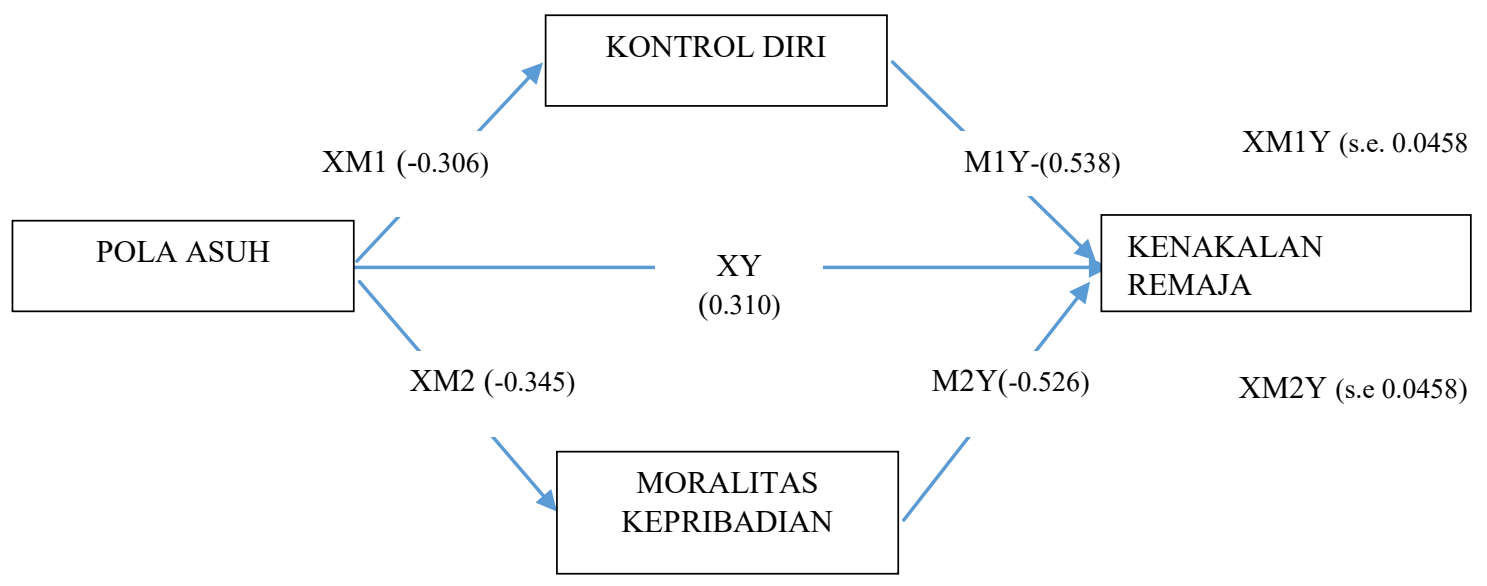

Bagan.2. Hasil Uji Pengaruh Tidak LangsungKontrol diri dan moralitas kepribadian dapat menjadi mediator pengaruh terhadap kenakalan

Hasil hitung koefisien kuadrat pengaruh pola asuh bersama kontrol diri terhadap kenakalan remaja memperlihatkan nilai yang lebih besar dari nilai koefisien kuadrat pengaruh pola asuh terhadap kenakalan. (PA terhadap KR <PAdan KD terhadap KR). Tabel. 3 menyajikan data $R^{2}$, data memperlihatkan $\mathrm{R}^{2}$ yang bertambah besar ketika kontrol diri diuji secara bersamaan dengan pola asuh yang buruk, secara langsung berpengaruh sebesar $9 \%$, setelah dimediasi meningkat menjadi $31.3 \%$. Meningkatnya presentase pengaruh tidak diartikan bahwa pola asuh memiliki pengaruh yang bertambah, justru hadirnya kontrol diri dapat menahan pengaruh langsung pola asuh terhadap kenakalan. Setiap 1 kali peningkatan pola asuh, diikuti dengan meningkatnya kenakalan sebesar 0.234. (<0.453). Hasil hitung dan hasil penelitian tersebut merepresentasikan bahwa kontrol diri dapat menjadi mediator untuk memengaruhi kenakalan remaja.

Hasil hitung dengan melibatkan moralitas kepribadian sebagai mediator mendapatkan fakta terjadinya pengaruh tidak langsung $(p<0.05)$ dan pengaruh langsung. Melanjutkan pengaruh pola asuh yang buruk terhadap kenakalan remaja. Maka dengan demikian interaksi antara pola asuh yang buruk terhadap kenakalan remaja dapat diteruskan oleh moralitas kepribadian. Hasil uji pengaruh langsung memperlihatkan bahwa moralitas kepribadian dapat memengaruhi kenakalan remaja. Analisis juga dilakukan dengan melibatkan moralitas menjadi mediator dalam hal pola asuh memengaruhi kenakalan remaja. Melalui nilai $R^{2}$ yang disajikan pada Tabel.3 memperlihatkan nilai yang $\mathrm{R}^{2}$ yang lebih besar ketika melibatkan moralitas sebagai mediator. Sama halnya dengan peran mediasi kontrol diri, bertambahnya nilai $\mathrm{R}^{2}$ tidak dapat diartikan bahwa pola asuh mempunyai pengaruh yang bertambah besar, karena harus melihat peranan mediasi dari moralitas. Pengaruh langsung sebesar $9 \%$, dan pengaruh ketika dimediasi moralitas menjadi $29.5 \%$. Penting untuk memperhatikan perbandingan nilai konstanta langsung dan nilai konstanta tidak langsung. Nilai konstanta saat pola asuh dimediasi moralitas menurun menjadi 0.214 (<0.453). Merujuk pada Baron and Kenny menyebutkan suatu variable disebut mediator jika variable tersebut ikut mempengaruhi hubungan antara variable prediktor dengan kriterion (Baron \& Kenny, 1986). Maka dengan demikian moralitas kembali terbukti dapat menjadi mediator, dalam kaitannya dengan keadaan lingkungan moralitas memengaruhi kenakalan remaja. 


\section{Pembahasan}

Pengasuhan orangtua dapat berdampak kepada terbentuknya tindak kenakalan anak telah banyak dikemukakan pada penelitian terdahulu. Penelitian berhasil mengungkap bahwa berubahnya pola asuh orangtua menjadi pengasuhan yang buruk mengakibatkan munculnya kenakalan pada anak remaja (Schroeder \& Mowen, 2014). Sejalan dengan hasil yang didapatkan dalam penelitian ini, bahwa proses pengasuhan dari orangtua sangat menentukan pembentukan perilaku anak di dalam kehidupannya sehari-hari. Pengasuhan orangtua menjadi tolak ukur bagi anak untuk membentuk dan mengembangkan pola perilakunya. Artinya ketika anak mendapatkan perlakuan pengasuhan yang buruk dari orangtuanya, anak dapat meniru setiap pengajaran yang diserapnya dan diekspresikan menjadi perilaku nakal, khususnya bentuk-bentuk perilaku yang melanggar aturan hukum pidana ataupun aturan hukum lainnya (aturan norma). Temuan penelitian yang pernah ada berhasil mengungkapkan bahwa keterlibatan hubungan positif antara anak dan orang tua dapat mengurangi perbuatan kenakalan anak, keterlibatan yang dimaksud adalah proses pengasuhan berupa pemantauan perilaku negatif anaknya (Gault-Sherman 2012).

Cara orangtua mengasuh anaknya menjadi faktor penting yang berpengaruh terhadap perilaku nakal anaknya, secara khusus berupa cara mengasuh yang buruk, berisi tentang pengasuhan yang dilakukan dengan mengajarkan perilaku negatif. Salah satu hal bentuk kenakalan yang mungkin terjadi adalah kriminogenik (Unnever et al., 2006), semacam regenerasi perilaku kriminal dari orangtua terhadap anaknya. Semakin anak besar nilai-nilai buruk yang diberikan orang tuanya, anak dapat menjadi lebih nakal lagi. Semakin anak terpapar dengan pengasuhan yang buruk perilakunya semakin bermasalah. Terpaparnya anak laki-laki oleh perbuatan kriminal dari dalam keluarga, dan kecenderungan melakukan perilaku yang bermasalah menjadi hal penting yang perlu diantisipasi atau ditangani untuk membantu remaja laki-laki tidak terjebak dalam tindak kenakalannya, karena remaja laki-laki yang paling mudah terkena dampaknya, inilah hal yang menyebabkan tingkat kenakalan anak laki-laki lebih berat dibandingkan dengan anak perempuan. Remaja dengan jenis kelamin laki-laki lebih banyak berurusan dengan penegakan hukum, merupakan remaja yang paling beresiko menjadi anak yang nakal (Blackmon et al., 2016)

Proses orangtua memantau perilaku anak-anaknya tidak seluruhnya dilakukan hanya dengan memberikan batasan dan monitoring tindakan kesehariannya. Proses lainnya dapat dilakukan dengan cara-cara membentuk kapasitas karakter diri yang kuat, yaitu dengan melatih membentuk kontrol diri pada anak. Hasil analisis yang diperoleh pada penelitian ini mendapatkan bahwa kontrol diri dapat berperan sebagai mediator, untuk mengungkap pengaruh tidak langsung pola asuh terhadap terbentuknya kenakalan. Pola asuh yang buruk dan tidak disertai dengan hadirnya pengajaran mengenai kontrol diiri dapat berpengaruh secara langsung terhadap kenakalan remaja (Jo \& Zhang, 2014). Sehingga kontrol diri menjadi variabel yang dapat menjelaskan mengenai proses adanya pengaruh tidak langsung dari pola asuh yang buruk terhadap terbentuknya kenakalan remaja. Pengaruh pengasuhan orangtua terhadap kenakalan anaknya sudah banyak ditemukan pada kasus-kasus remaja bermasalah, tetapi ternyata kontrol diri yang kuat justru ditemukan pada remaja yang tidak bermasalah. Pengasuhan negatif berpengaruh secara langsung kecenderungan untuk ikut berbuat nakal, tetapi adanya kontrol diri kuat dapat menghambatnya untuk tidak melakukannya, sedangkan kontrol diri yang lemah justru menguatkan remaja untuk terlibat dalam kasus-kasus pelanggaran dan kekerasan (Muftic and Updegrove 2018).

Selain pengaruh langsung dari pola asuh yang buruk, ternyata ada faktor risiko yang lainnya, yaitu moralitas yang melekat di dalam diri pribadi remaja, dimana moralitas kepribadian memberikan pengaruh langsung terhadap kenakalan remaja (Jevtić, 2014). Dalam hal ini moralitas kepribadian tidak bisa dilihat sebagai variabel yang dapat mempengaruhi langsung kenakalan remaja, tetapi perlu dilihat melalui perannya sebagai mediator (Bao et al., 2015), yang memediasi 
pola asuh buruk dalam memberikan pengaruh terhadap kenakalan remaja. Moralitas dapat menjadi mediator ketika membentuk pola pikir pada remaja yang cenderung menghindari perilaku pada kasus-kasus dengan tingkat kenakalan yang ringan, berbeda untuk tingkat kenakalan yang berat moralitas tidak dapat berperan menjadi mediator (Piquero et al., 2016). Salah satu bentuk efek jera yang dimaksud adalah terbentuknya sikap moral tentang perilaku yang etis dan saling membantu. Sikap moral yang tidak tepat dengan tuntutan norma lingkungan dapat membentuk individu sulit untuk tidak ikut serta dalam tindak kejahatan (Herman \& Pogarsky 2020).

Hasil analisa data memperlihatkan terjadinya perbedaan komparatif antara kenakalan subjek laki-laki dan perempuan. Hal ini mengindikasikan bahwa jenis kelamin mengambil bagian di dalam deskripsi kenakalan remaja, jenis kelamin menjadi hal yang dapat digunakan dalam menjelaskan karakteristik perilaku kenakalan. Jenis kelamin dapat dijadikan sebagai variabel dikotomi yang dapat digunakan untuk membandingkan kenakalan antara laki-laki dan perempuan (Jo \& Zhang, 2014). Remaja perempuan memiliki tingkatan yang lebih rendah dibandingkan dengan remaja laki, hal ini dilihat melalui kenakalan saat perempuan berursan dengan polisi adalah perbuatan yang dilakukannya tidak lebih serius dibandingkan dengan ketika remaja laki-laki berurusan dengan polisi. Standar minimal delinquency perempuan lebih rendah dibandingkan dengan standar delinquency remaja laki-laki. Jika keduanya memiliki standar delinquency yang sama, hal ini disebabkan karena remaja perempuan berada di bawah pengaruh remaja laki-laki (Pazzani, 2017). Sebuah hasil studi memberikan gambaran perbedaan bentuk perbuatan kenakalan remaja lakilaki dan perempuan. Remaja laki lebih kuat dalam hal kenakalan yang berkaitan dengan perbuatan menyerang dan mengambil milik orang lain. Remaja perempuan terlibat dalam hal mengambil ditempat perbelanjaan (shoplifting), dan lebih rendah dalam perbuatan menyerang orang lain (Weerman \& Hoeve, 2012).
Pengasuhan orangtua yang negatif tidak selamanya ditemukan pada anak remaja berdasarkan menjalankan pendidikan di sekolah swasta. Sebaliknya remaja yang bersekolah negeri justru mengalami pengasuhan yang lebih negatif dibandingkan dengan anak remaja yang bersekolah di swasta. Sepertinya keadaan inilah yang menjadi alasan mengapa siswa sekolah negeri lebih banyak terlibat dengan tindak kenakalan, khususnya tindak kekerasan. Hasil penelitian yang dilakukan terhadap siswa SMA memperlihatkan siswa SMA negeri memiliki tingkat agresivitas yang lebih tinggi dibandingkan dengan siswa SMA swasta (Fitriana \& Pa, 2018). Tindak kekerasan ataupun bentuk kenakalan yang lainnya memang tidak hanya dapat dijelaskan melalui pendidikan dan jenis kelamin.

Hasil analisis data mendapatkan fakta bahwa nilai rata-rata kontrol diri subjek yang orang tuanya lengkap lebih tinggi dibandingkan denngan yang orang tuanya tidak lengkap, nilainya berbeda secara signifikan. Keadaan orangtua yang berpisah atau broken home dapat menjadi faktor yang beresiko membuat anak menjadi nakal (Nisar et al., 2015). Hal tersebut sejalan dengan hasil yang diperoleh dari analisis data memperlihatkan bahwa kontrol diri yang rendah, dapat ditemukan pada kelompok subjek yang keadaan orangtuanya tidak lengkap. Namun penting untuk diperhatikan bahwa tidak lengkapnya orangtua yang dihimpun dalam penelitian ini tidak hanya yang bercerai hidup, termasuk juga bercerai meninggal dan keduanya sudah meninggal. Catatan yang dapat dijadikan sebagai temuan dalam penelitian ini adalah tidak lengkapnya orangtua dimaksudkan untuk menjelaskan terjadinya kekosongan peran orangtua dalam memberikan pengajaran tentang cara menahan diri dan bersikap sesuai nilai-nilai moral positif. Hasil yang diperoleh dalam penelitian ternyata dapat dikuatkan dengan penelitian yang pernah ada, yang mengungkap bahwa kontrol diri lemah yang disebabkan karena kekosongan peran orangtua dalam memberikan pengajaran dan pembentukan kemampuan mengenai cara mengendalikan diri sendiri (Pung et al., 2015). 


\section{Kesimpulan}

Penelitian menemukan fakta bahwa kenakalan remaja adalah konsekuensi langsung dari pola pengasuhan buruk yang diberikan orangtuanya Pola asuh yang negatif dari orang tua berperan sebagai faktor yang dapat memengaruhi terbentuknya kenakalan remaja. Pola asuh yang buruk dari orangtua secara bersama-sama berinteraksi di dalam fenomena keterlibatan remaja menjadi pelaku kenakalan. Interaksinya bergerak searah, dalam kondisi pengasuhan orang tua bertambah buruk, kenakalan anak remaja akan ikut meningkat. Interaksi antara pola asuh yang buruk terhadap kenakalan remaja juga dapat terjadi dalam interaksi tidak langsung. Kontrol diri berhasil berperan menjadi modiator, menjadi variabel yang menghubungkan pola asuh buruk dengan kenakalan remaja. Dampak mediasi kontrol diri mengakibatkan terjadinya penurunan dampak, efek mediasi mengakibatkan terjadinya pengaruh yang lebih rendah dibandingkan dengan pengaruh langsung. Moralitas kepribadian terbukti dapat berperan sebagai variabel mediator, menjadi variabel yang mengantarai pengaruh pola asuh buruk terhadap kenakalan remaja.

\section{Daftar Pustaka}

Azwar, S. (2009). Efek seleksi aitem berdasar daya diskriminasi terhadap reliabilitas skor. Buletin Psikologi, 17(1), 28-32.

Bao, Z., Zhang, W., Lai, X., Sun, W., \& Wang, Y. (2015). Parental attachment and Chinese adolescents' delinquency: The mediating role of moral disengagement. Journal of Adolescence, 44(55), 37-47. https://doi. org/10.1016/j.adolescence.2015.06.002

Baron, R. ., \& Kenny, D. . (1986). The moderatorâ mediator variable distinction in social psychological research 1986. pdf. Journal Of Personality and Social Psychology, 51(6), 1173-1182.

Bertok, E., \& Mesko, G. (2015). Self-control and morality in Slovenian Primary and Secondary school sample: the results of youth prev study. Journal Of Criminal Justice and Security, 4., 480-493.
Blackmon, B. J., Robison, S. B., \& Rhodes, J. L. . (2016). Examining the influence of risk factors across rural and urban communities. . Journal of the Society for Social Work and Research, 7(4), 615638. https://doi.org/org/10.1086/689355

Delisi, M., Hochstetler, A., \& Murphy, D. S. (2003). Self-control behind bars: a validation study of the Grasmick et al scale. Journal Justice Quarterly, 2, 241263.

Dirdjosisworo, S. (1983). Penanggulangan Kejahatan. Penerbit Alumni.

Fitriana, Y., \& Pa, D. (2018). Faktor yang berkontribusi terhadap perillaku agressif pada remaja berbeda antara SMA negeri dan SMA swasta. Jurnal Kebidanan Dan Keperawatan, vol 14 no, 168-176.

Frimer, J. A., Walker, L. J., Dunlop, W. L., Lee, B. H., \& Riches, A. (2011). The Integration of Agency and Communion in Moral Personality: Evidence of Enlightened Self-Interest. Journal of Personality and Social Psychology, 101(1), 149-163. https://doi.org/10.1037/a0023780

Gault-Sherman. E. (2012). It's a two way street: the biderectional relationship between parenting and delinqunecy. Journal of youth and adolesncence. 41 (2), 121-145.

Guglielmo, S., \& Malle, B.F. (2019). Asymetric morality: blame is more differetaited and more extreme than praise. Plos one 14 (3).

Herman, S., \& Pogarsky, G. (2020). Morality, deterrability, and offender decision making. Justice Quarterly. 1-25. DOI 10. 1080/07418825.2019.1709884

Jevtić, B. (2014). Moral Judgement of Delinquents. Procedia - Social and Behavioral Sciences, 149, 449-455. https://doi.org/10.1016/j.sbspro. 2014.08.286

Jo, Y., \& Zhang, Y. (2014). Parenting, selfcontrol, and delinquency: Examining the applicability of gottfredson and hirschi's general theory of crime to South Korean youth. International Journal of Offender Therapy and Comparative Criminology, 58(11), 1340-1363. https:// doi.org/10.1177/0306624X13494670 
Li, S. D. (2014). Familial Religiosity, Family Processes, and Juvenile Delinquency in a National Sample of Early Adolescents. Journal of Early Adolescence, 34(4), 436-462.https://doi.org/10.1177/ 0272431613495445

Muftic, L. R., \& Updegrove, A. H. (2018). The mediating effect of self-control on parenting and delinquency: a gendered approach with multinational sample. International Journal of Offender Therapy and Comparative Criminology. 62 (10), 3058-3076.

Narvaez, D., \& Lapsley. (2014). Becoming a Moral Person. Empirically Informed Ethics. Morality Between Facts and Norms, 5(13), 227-238.

Nas, C. N., Brugman, D., \& Koops, W. (2005). Effects of the EQUIP programme on the moral judgement, cognitive distortions, and social skills of juvenile delinquents. Psychology, Crime and Law, 11(4), 421-434. https://doi. org/10.1080/10683160500255703

Nisar, M., Ullah, S., Ali, M., \& Alam, S. (2015). Juvenile Delinquency: The Influence of Family, Peer and Economic Factors on Juvenile Delinquents. https://doi. org/10.15192/PSCP.ASR.2015.9.1.3748

Owens, S., \& Cecilia, M. (2007). The effects of race and family attachment on selfesteem, self-control, and delinquency. Lfb Scholarly Pub Llc.

Pazzani, L. (2017). Gender (Correlations and Contexts of Delinquency). The Encyclopedia of Juvenile Delinquency and Justice, 1-3. https://doi.org/10.1002/ 9781118524275.ejdj0195

Piquero, A. R., Hawkins, J. D., \& Kazemian, L. (2012). Criminal Career Patterns. In R. Loeber \& D. P. Farrington (Eds.), From Juvenile Delinquency to Adult Crime (Criminal Careers, Justice Policy, and Prevention) (pp. 14-46). Oxford.

Piquero, A.R., Boufard, J.A., Piquero, N.L., Craig, J.M. (2016). Does morality condition the deterrent effect of preceived certainty among incarcerated felons? Crime and Dlinquency 62 (1), 3-25.

Pratt, T. C., Turanovic, J. J., Fox, K. A., \& Wright, K. A. (2014). Self-control and victimization: A meta-analysis.
Criminology, 52(1), 87-116. https://doi. org/10.1111/1745-9125.12030

Preacher, K. ., \& Hayes, A. F. (2004). SPSS and SAS procedures for estimating indirect effects in simple mediation models. Behavior Research Methods, Instruments, \& Computers, 36, 717-731.

Pung, P.-W., Yaacob, S. ., Baharudin, R., \& Osman, S. (2015). Low self-control, peer delinqunecy and agression among adolescents in Malaysia. Asian Social Science, 11(21). https://doi.org/10.5539/ ass.v1 $1 \ln 21 \mathrm{p} 193$

Rekker, R., Pardini, D., Keijsers, L., Branje, S., Loeber, R., \& Meeus, W. (2015). Moving in and out of poverty: The with in-individual association between socioeconomic status and juvenile delinquency. Plos One, 10(11). https:// doi.org/10.1371/journal.pone.0136461

Schroeder, R. D., \& Mowen, T. J. (2014). Parenting Style Transitions and Delinquency. Youth and Society, 46(2), 228-254.https://doi.org/10.1177/ $0044118 \times 12469041$

SDP. (2013). Sistem Data Base Pemasyarakatan 2013. In Web SDP.

SDP. (2014). Sistem Data Base Pemasyarakatan 2014. In Web SDP.

SDP. (2015). Sistem Data Base Pemasyarakatan 2015. Web SDP.

Stams, G. ., Brugman, D., Dekovic, M., \& Gibs. (2006). The moral judgement of juvenile delinquents: a meta-analysis. Journal Abnorm Child Psychol, 34, 697-713.

Sudarsono. (2004). Kenakalan Remaja. Rineka Cipta.

Unnever, J. ., Cullen, F. ., \& Agnew, R. (2006). Why is 'bad' parenting criminogenic? Implications froem rival theories. Youth Violance and Juvenile Justice, 4(1), 3-33. https://doi.org/10.1177/ 1541204005282310

Uprichard. E. (2013). Sampling bridging probability and non-probability designs. International Journal of Social Science Research Methodology. 16 (1), 1-11.

Wang,X.. ,Lei, L. .,Yang, J., Gao, L.,\& Zhao, F. (2016). Moral Disengagement as Mediator and Moderator of the Relation Between Empathy and Aggresion Among Chinese Male Juvenile Delinquent. Child 
Psychiatry Hum Dev, 48, 316-326.

Weerman, F. M., \& Hoeve, M. (2012). Peersand

delinquency among girls and boys: Are

sex differences in delinquency explained

by peer factors? European Journal of

Criminology, 9(3), 228-244. https://doi.

org/10.1177/1477370811435736 